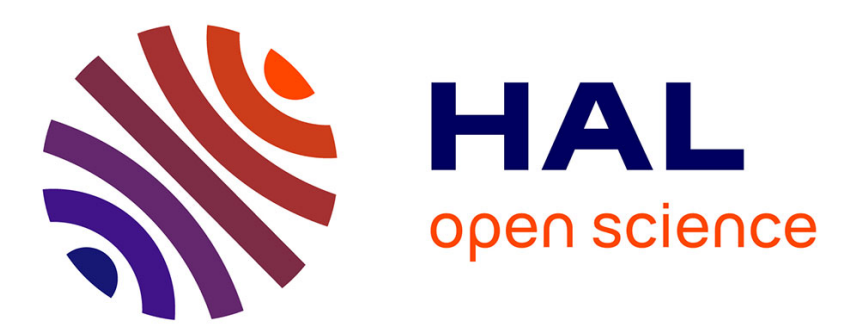

\title{
Acerola pollinators in the savanna of Central Brazil: temporal variations in oil-collecting bee richness and a mutualistic network
}

\author{
Alice Vilhena, Laíce Rabelo, Esther Bastos, Solange Augusto
}

\section{- To cite this version:}

Alice Vilhena, Laíce Rabelo, Esther Bastos, Solange Augusto. Acerola pollinators in the savanna of Central Brazil: temporal variations in oil-collecting bee richness and a mutualistic network. Apidologie, 2011, 43 (1), pp.51-62. 10.1007/s13592-011-0081-1 . hal-01003619

\section{HAL Id: hal-01003619 https://hal.science/hal-01003619}

Submitted on 1 Jan 2011

HAL is a multi-disciplinary open access archive for the deposit and dissemination of scientific research documents, whether they are published or not. The documents may come from teaching and research institutions in France or abroad, or from public or private research centers.
L'archive ouverte pluridisciplinaire HAL, est destinée au dépôt et à la diffusion de documents scientifiques de niveau recherche, publiés ou non, émanant des établissements d'enseignement et de recherche français ou étrangers, des laboratoires publics ou privés. 


\title{
Acerola pollinators in the savanna of Central Brazil: temporal variations in oil-collecting bee richness and a mutualistic network
}

\author{
Alice Maria Guimarães Fernandes VILHEnA ${ }^{1}$, Laíce Souza Rabelo ${ }^{1}$, \\ Esther Margarida Alves Ferreira Bastos ${ }^{2}$, Solange Cristina Augusto ${ }^{1}$

\footnotetext{
${ }^{1}$ Instituto de Biologia, Universidade Federal de Uberlândia, Rua Ceará, s/n, Umuarama, 38400-902 Uberlândia, MG, Brazil

${ }^{2}$ Laboratório de Recursos Vegetais e Opoterápicos, Fundação Ezequiel Dias, Rua Conde Pereira Carneiro, 80,
} \\ Gameleira, Belo Horizonte, MG, Brazil
}

Received 2 February 2011 - Revised 24 May 2011 - Accepted 7 July 2011

\begin{abstract}
We present parameters to support the conservation and management of Acerola pollinators. We monitored pollinator visits to this fruit shrub in a Brazilian savanna and identified the pollinator's other food resources. Twenty-three species of pollinators were sampled. Although there were temporal variations in visitor frequency, satisfactory levels of fruit set were obtained. This temporal variation promoted a compensatory effect on plant reproduction as the pollinator species were replaced during the course of flowering. The analysis of pollen loads showed grains of 16 plant species and four pollen types belonging to seven families that formed a network with a nested pattern. Such a network suggests that generalist plants must be available in the crop vicinity. The data presented suggest the natural viability of cultivating Acerola in the savannas of Central Brazil and the importance of natural lands for providing nesting resources and to enhance the bee diversity in agroecosystems.
\end{abstract}

Centridini / agriculture / pollination / interaction network / bee

\section{INTRODUCTION}

Pollination is an essential mechanism for maintaining the genetic variability of plants (Richards 1986), and it has been defined as the most important benefit that bees provide to humanity and nature. Native plants and cultivars depend on a wide diversity of bees, which can increase production and improve fruit quality (Williams et al. 1991). It is estimated that 87 of the 115 main global cultivars, representing 35\% of the food supply, significantly benefit from the presence of pollinators (Klein et al. 2007), with

Corresponding author: S.C. Augusto, scaugusto@umuarama.ufu.br Manuscript Editor: Marla Spivak bees being the most important group among them (Roubik 1995; Klein et al. 2007).

Acerola (Malpighia emarginata), also called West Indian cherry, is an important fruit crop in Brazil, and its fruit is exported and consumed due to its high vitamin $\mathrm{C}$ content. The latest official data concerning the cultivation of Acerola in Brazil reported a harvested area of approximately 3,563 ha, considering properties with more than 50 plants (IBGE 2006).

Although the Acerola is not a common cultivar in the Triângulo Mineiro region (in the state of Minas Gerais), this area presents ideal agroclimatic attributes for its production (Souza et al. 2006). Furthermore, the region is located in the Cerrado biome, which is home to a great variety of pollinators, including oil-collecting 
bees (Silveira and Campos 1995; Carvalho and Bego 1996).

Acerola orchards frequently have low fruit set in spite of abundant flowering. One possible explanation for these fruit set rates would be a lack of effective pollination (Yamane and Nakasone 1961), which depends on the presence of conserved areas of vegetation in the vicinity of orchards to maintain the population of natural pollinators.

Although the Acerola is visited and occasionally pollinated by other bees, Centridini bees are the most frequent and effective pollinators (Freitas et al. 1999; Vilhena and Augusto 2007; Oliveira and Schlindwein 2009). Centridini species primarily visit the flowers of this plant to collect oil. In order to collect this resource, the females hold the base of the posterior flower petal with their mandibles and scratch the elaiophores with alternating movements of the forelegs and middle legs. The collected oil is then transported in the scopae located on the posterior legs. During collection, the ventral region of the body comes into contact with anthers and stigmas, which makes these bees effective pollinators of this plant species (Vilhena and Augusto 2007).

It is known that pollinators establish mutualistic interactions with many plant species in order to collect resources to provision their cells. These interactions can be identified from pollen analysis and can be approached from the perspective of an ecological network that provides a visual model of how species are interconnected, the relative strength of the links, and the system properties (Bascompte 2007). Most mutualistic networks are nested (Guimarães et al. 2007), and we expected to identify this pattern in Centridini bees, with strong connections between these bees and oil plant species.

Considering the importance of the Acerola crop in Brazil and its requirement for natural pollination by Centridini bees, the general aim of this study was to assess the richness and frequency of these bees in an experimental Acerola orchard and the influence of temporal variations in these parameters on yield. Addi- tionally, we examined important resources required by these bees that are not collected or offered by the crop. The results suggest that the high species richness of Centridini and the stability of the pollination network may promote a compensatory effect on Acerola crops that, despite temporal variations in the frequency of individuals, ensures good rates of natural pollination. They also suggest that the occurrence of natural vegetation surrounding the crop can enhance bee diversity and benefit agricultural production.

\section{MATERIALS AND METHODS}

\subsection{Study site}

This study was carried out on an Acerola orchard at the Água Limpa Experimental Station (19 $05^{\prime} 48^{\prime \prime}$ $\mathrm{S} / 48^{\circ} 21^{\prime} 05^{\prime \prime} \mathrm{W}$ ), which belongs to the Federal University of Uberlândia, Uberlândia, Minas Gerais, Brazil. The station includes 104 ha of a preserved area and 151.72 ha of crops and pastures, with 43 ha of orchards including Acerola, pineapple, guava, passion fruit, citrus varieties, and mango (Neto 2008). The Acerola plantation covers an area of 1.1 ha and includes approximately 700 shrubs. The vegetation complex in the surrounding area includes a preserved area of Cerrado sensu stricto, palm swamp, and gallery forest. The mixed system proved to be adequate for the objectives of this study because its features allow long-term studies and ensure a continual bee presence in the area.

\subsection{Malpighia emarginata}

The Acerola produces small inflorescences in the leaf axils (Miyashita et al. 1964) consisting of two to six flowers (Freitas et al. 1999). The flowers only last for 1 day and most of them present anthesis between 4:00 and 5:00 A.M. (Freitas et al. 1999; Oliveira and Schlindwein 2003; A.M.G.F. Vilhena personal observation). However, in the present study, we observed that anther dehiscence started at 8:00 A.M.

In the study area, the flowering season occurs from October to February and may extend until March, depending on regional rainfall. The studied crop received no pesticide treatment. 
Acerola pollination is dependent on flower visitors and probably more than one visit is required to achieve an optimal number of fruit (Freitas et al. 1999). In order to determine the percentage of natural pollination, 60 flowers were marked on the shrubs observed in each day of observation $(n=24)$, and fruit formation was verified on subsequent field trips.

\subsection{Monitoring of the frequency of Centridini bees}

Field work was carried out three times a month in October, November, January, and February, amounting to 12 sampling trips per year (year $1=2006 / 2007$ and year $2=2007 / 2008$ ) during the flowering period. The months of October and November were considered as period 1 and the months of January and February as period 2. Thus, we used the following terminology: $\mathrm{P}_{1} / \mathrm{Y}_{1}$ (period 1 of year 1 ), $\mathrm{P}_{2} / \mathrm{Y}_{1}$ (period 2 of year 1), $\mathrm{P}_{1} / \mathrm{Y}_{2}$ (period 1 of year 2), and $\mathrm{P}_{2} / \mathrm{Y}_{2}$ (period 2 of year 2 ).

We recorded the number of bee visits to Acerola flowers for $4.5 \mathrm{~h}$ during each field trip, equally divided between morning (beginning at 8:00 A.M.) and afternoon (ending at 4:00 P.M.) sessions, totalling $108 \mathrm{~h}$ of observation. The observations were carried out in three previously selected crop rows, in which all the shrubs that presented inflorescences were observed. A single researcher performed all frequency observations. The researcher walked along the inter-rows and stopped for about $5 \mathrm{~min}$ at each flowering shrub only recording (using a voice recorder) the visits of Centridini bees. When a visiting bee species was unknown, a specimen was netted and later deposited at the Entomological Collection of the Federal University of Uberlândia for identification. The number of flowering shrubs per row was always around seven full blooming individuals.

\subsection{Plant resources}

Pollen grains found on the scopae of Centridini visitors were collected to identify their plant resources. Individuals were collected during the period of Acerola flowering in the years 2004 to 2008, after they had visited flowers of $M$. emarginata. This procedure was performed for seven species that were chosen from the criteria of the species recorded in all years and those presenting the largest number of individuals with pollen in the scopae. For each species, six individuals were sampled, i.e., six pollen loads.

Each specimen's pollen load was removed with a stylus and stored in 70\% isopropyl alcohol. The pollen was then prepared for analysis using the acetolysis method (Erdtman 1960), which eliminated the intine, cytoplasm, and substances adhering to the grains while isolating the exine for detailed investigation. After the grains had been prepared, three slides for each individual were prepared for qualitative and quantitative analysis, totalling 126 slides. These were mounted with glycerin jelly prepared using Kisser's method (Kearns and Inouye 1993), covered with coverslips, and stored in the pollen slide collection of the Laboratory of Plant Morphology, Microscopy and Imaging of the Federal University of Uberlândia (LAMOVI-IB/UFU).

For qualitative analysis, the botanical species or pollen types were determined by comparing the grain morphology of collected samples with a reference slide collection consisting of plants from the study site. Specialized literature was also consulted (Salgado-Labouriau 1973; Roubik and Moreno 1991).

Some pollen grains were grouped into pollen types (i.e., sets of grains with a similar morphology) (Maia et al. 2005), regardless of whether or not they belonged to species of the same genus. We adopted the following pollen types:

1. Banisteriopsis type: Banisteriopsis campestris and Banisteriopsis stellaris;

2. Heteropterys type: Heteropterys pteropetala, Heteropterys anoptera, and Tetrapterys sp;

3. Byrsonima type: Byrsonima intermedia, Byrsonima coccolobifolia, Byrsonima pachyphylla, Byrsonima verbascifolia, and Pterandra pyroidea;

4. Myrcia type: Myrcia uberavensis, Myrcia rostrata, Myrcia variabilis, Myrcia rubella, Myrcia canescens, and Myrcia rodocephala.

Quantitative analysis was performed by dividing the cover slip into four quadrants, with about 100 grains counted in each quadrant, totalling approximately 1,200 grains per sampled bee. We counted all 
pollen grains in quadrants that contained less than 100 grains. The pollen grains were grouped by botanical species or pollen type. It should be noted that the pollen for analysis was only taken from the scopae of females, which avoided overestimating $M$. emarginata pollen from the ventral part of the body picked up during oil collection visits. We excluded species and pollen types from the samples that presented an abundance of less than ten grains, considering them as contaminants.

\subsection{Data analysis}

\subsubsection{Centridini bee frequency in the Acerola orchard}

Species relative frequency was determined by dividing the number of visits from each species by the total number of observed visits: $F=(\mathrm{ni} / N) \times 100$, where $\mathrm{ni}=$ number of species visits and $N=$ total number of visits.

A species accumulation curve was constructed using EstimateS 8.00 software (Colwell 2006). In order to estimate pollinator richness in the study area, we used the following estimators: Incidence-Based Coverage Estimator (ICE), which considers the number of infrequent species (i.e., those that appear in few sample units); Chao 2, which is based on singletons and doubletons; and first-order and second-order Jackknife procedures, which estimate the total richness and add a parameter calculated from the number of rare species and samples (see EstimateS User's Guide in Colwell 2006).

We tested possible differences between the total number of bee visits and fruit formation during both periods and years using the model III two-factor ANOVA. The same analysis was made using only the total number of visits performed by the nine most frequent species. The data about bee visitation were transformed (log visits +1$)$ to achieve homoscedasticity (Zar 1999).

We used Pearson's correlation to verify the association between the number of visits and the number of fruits formed. Both parameters were transformed into square root +0.5 (Zar 1999).

One-factor ANOVA was used to compare the number of visits by each of the nine most abundant bee species for each year separately (Zar 1999). All statistical analyses were performed using Systat 10.2 software.

\subsubsection{Network analysis between Acerola visitors and their food resources}

A network between the bees and plants was established using data from the pollen analysis. We organized the data into an adjacency matrix with bee species listed as rows and pollen types as columns. First, each cell was filled 1 (presence of interaction) or 0 (absence of interaction). Second, the cells were filled with the number of pollen grains from each plant species recorded for each bee species.

We used a binary data matrix to calculate the degree of network nestedness according to the Nestedness Metric Based on Overlap and Decreasing Fill (NODF) (Almeida-Neto et al. 2008). In order to calculate the degree of nestedness, we used Aninhado software, which allows the significance of measures with two null models to be tested (Guimarães and Guimarães 2006). The first null model (ER) assumes that the interaction probability is the same for all cells (a random process). In the second null model (CE), the interaction probability is proportional to the degree of generality of each species involved in the interaction (Bascompte et al. 2003). The second matrix was used to construct a bipartite graph using Pajek 1.2.4 software (Batagelj and Mrvar 1998).

In order to describe the network structure, we calculated the connectance $(C)$, the mean degree of bee species and pollen types, and their richness ratio. The connectance percentage was calculated using $C=$ $(E / A \times P) \times 100$, in which $E$ corresponded to the number of observed interactions, $A$ to the number of bees species, and $P$ to the number of botanical species or pollen types (Pigozzo and Viana 2010). The richness ratio was considered as the ratio between the number of bee species and pollen types (Pigozzo and Viana 2010). The mean degree was obtained from the arithmetic average of all interactions (degree), considering bees and botanical species or pollen types separately (Pigozzo and Viana 2010).

\section{RESULTS}

\subsection{Bees and fruit set}

A high richness of Centridini bees was observed visiting $M$. emarginata flowers during 
both $\mathrm{Y}_{1}$ (21 species) and $\mathrm{Y}_{2}$ (18 species) (Table I).

Only the species accumulation curve for both sampled years added showed a tendency towards stabilization (Figure 1), indicating that a sufficient effort was made to sample almost all of the species of Centridini that visit Acerola shrubs in the study area. The richness estimators (Table II) indicated that the number of species observed was similar to the estimated number.
The total number of visits significantly differed between the years $\left(F_{1,18}=4.920, P=0.040\right)$, with $\mathrm{Y}_{2}$ having a higher number of visits (Figure 2a). During both years, two species made more than $50 \%$ of the observed visits: Centris (Centris) varia and Centris (Hemisiella) tarsata (59.95\%) in $\mathrm{Y}_{1}$ and Centris (Centris) aenea and C. (C.) varia $(66.97 \%)$ in $Y_{2}$. No differences were found between the periods $\left(F_{1,1}=52.702,0.10<P<\right.$ $0.20)$ and there were no interactions between the factors (period and year) $\left(F_{1,18}=0.081, P=0.780\right)$.

Table I. Species richness, number of Centridini bee visits to Malpighia emarginata flowers and relative frequency, observed at the Água Limpa Experimental Station, between October and November of 2006 and 2007 and in January and February of 2007 and 2008.

\begin{tabular}{|c|c|c|c|c|}
\hline \multirow[t]{2}{*}{ Species } & \multicolumn{2}{|c|}{$2006 / 2007$} & \multicolumn{2}{|c|}{$2007 / 2008$} \\
\hline & $\begin{array}{l}\text { Number } \\
\text { of visits }\end{array}$ & $\begin{array}{l}\text { Relative } \\
\text { freq. }\end{array}$ & $\begin{array}{l}\text { Number } \\
\text { of visits }\end{array}$ & $\begin{array}{l}\text { Relative } \\
\text { freq. }\end{array}$ \\
\hline Centris (Centris) varia (Erichson, 1848) & $140 \mathrm{~b}$ & 40.35 & $199 \mathrm{c}$ & 25.98 \\
\hline Centris (Hemisiella) tarsata Smith, 1874 & $68 \mathrm{~b}$ & 19.6 & $17 \mathrm{ab}$ & 2.22 \\
\hline Centris (Centris) flavifrons (Fabricius, 1775) & $32 \mathrm{ab}$ & 9.22 & $12 b$ & 1.57 \\
\hline Epicharis (Epicharoides) albofasciata Smith, 1874 & $16 \mathrm{a}$ & 4.61 & $3 b$ & 0.39 \\
\hline Centris (Centris) spilopoda Moure, 1969 & $14 \mathrm{a}$ & 4.03 & $16 \mathrm{ab}$ & 2.09 \\
\hline Centris (Centris) aenea Lepeletier, 1841 & $13 \mathrm{a}$ & 3.75 & $314 \mathrm{a}$ & 40.99 \\
\hline Centris (Heterocentris) analis (Fabricius, 1804) & $13 \mathrm{a}$ & 3.75 & $87 \mathrm{a}$ & 11.36 \\
\hline Centris (Trachina) longimana Fabricius, 1804 & $11 \mathrm{a}$ & 3.17 & $3 b$ & 0.39 \\
\hline Centris (Centris) nitens Lepeletier, 1841 & $8 \mathrm{a}$ & 2.31 & $87 \mathrm{ab}$ & 11.36 \\
\hline $\begin{array}{l}\text { Epicharis (Epicharoides) xanthogastra Moure \& } \\
\text { Seabra, } 1959\end{array}$ & 6 & 1.73 & 0 & 0 \\
\hline Centris (Melacentris) mocsaryi Friese, 1899 & 5 & 1.44 & 0 & 0 \\
\hline Centris (Ptilotopus) denudans Lepeletier, 1841 & 4 & 1.15 & 0 & 0 \\
\hline Centris (Hemisiella) vittata Lepeletier, 1841 & 4 & 1.15 & 1 & 0.13 \\
\hline Epicharis (Epicharitides) cockerelli (Friese, 1900) & 3 & 0.86 & 0 & 0 \\
\hline Epicharis (Epicharana) flava (Friese, 1900) & 3 & 0.86 & 7 & 0.91 \\
\hline Epicharis (Epicharis) bicolor Smith, 1874 & 2 & 0.58 & 10 & 1.31 \\
\hline Centris (Xanthemisia) bicolor Lepeletier, 1841 & 1 & 0.29 & 0 & 0 \\
\hline Centris (Ptilotopus) scopipes Friese, 1899 & 1 & 0.29 & 1 & 0.13 \\
\hline Epicharis (Hoplepicharis) affinis Smith, 1874 & 1 & 0.29 & 4 & 0.52 \\
\hline Epicharis (Triepicharis) analis Lepeletier, 1841 & 1 & 0.29 & 1 & 0.13 \\
\hline Centris (Centris) inermis Friese, 1899 & 1 & 0.29 & 2 & 0.26 \\
\hline Centris (Centris) poecila Lepeletier, 1841 & 0 & 0 & 1 & 0.13 \\
\hline \multirow[t]{2}{*}{ Centris (Trachina) fuscata Lepeletier, 1841} & 0 & 0 & 1 & 0.13 \\
\hline & 347 & 100 & 766 & 100 \\
\hline
\end{tabular}

Different letters indicate significant differences in the Tukey test $(\alpha=5 \%)$ 


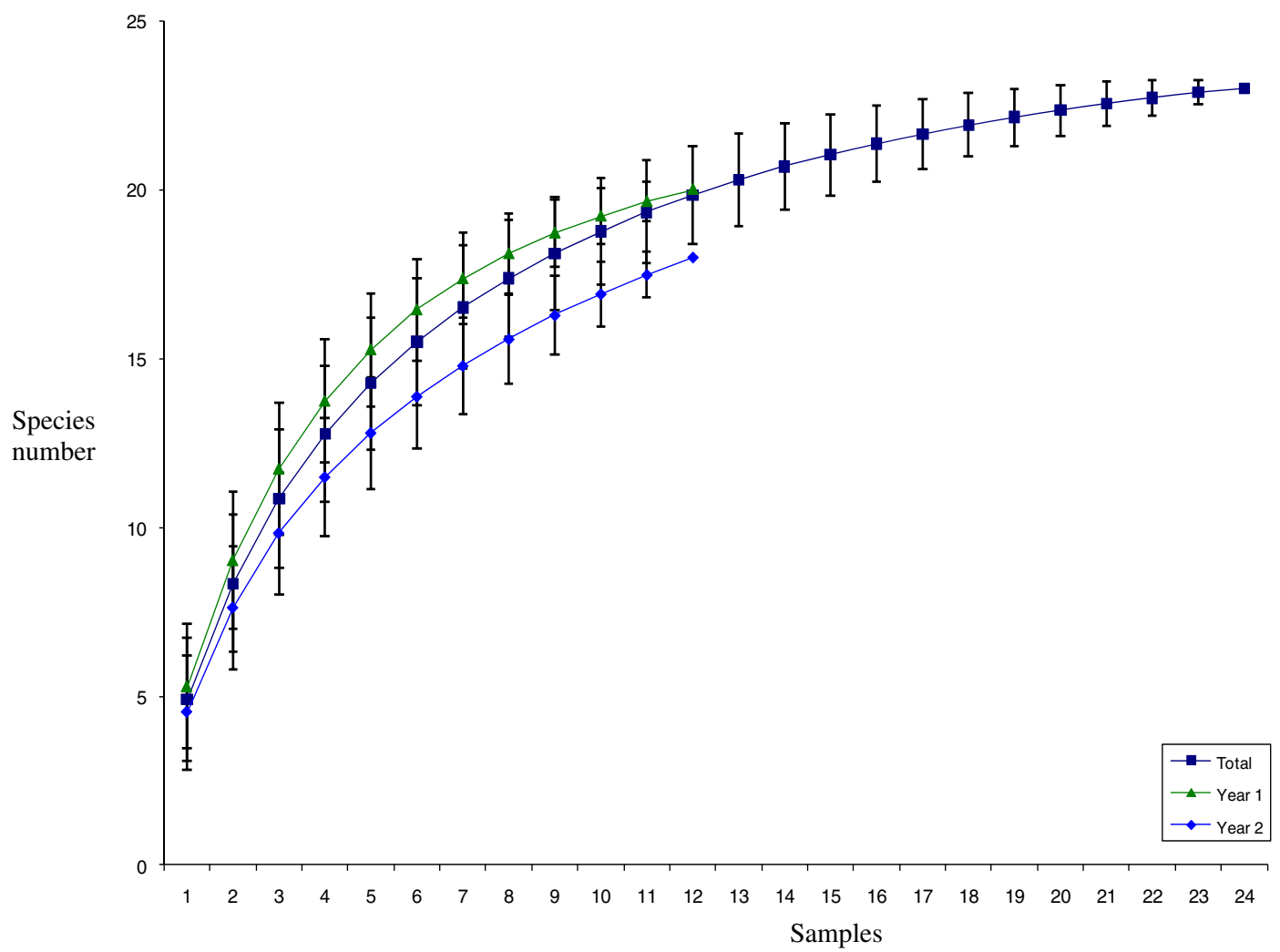

Figure 1. Cumulative number of Centridini species $( \pm \mathrm{SD})$ per sample (1 day of observation) in an area of Acerola orchard (Malpighia emarginata) in each year (year 1-2006-2007 and year 2-2007-2008) and in both years combined (Total). Água Limpa Experimental Station, Uberlândia, MG.

When the nine most frequent species $[C$. (C.) varia, C. (H.) tarsata, Centris (Centris) flavifrons, Epicharis (Epicharoides) albofasciata, Centris (Centris) spilopoda, C. (C.) aenea, Centris (Heterocentris) analis, Centris(Trachina) longimana, and Centris (Centris) nitens] were considered jointly (Table I), it was found that their fluctuations in the number of visits (Figure 3) significantly differed between the years $\left(F_{8,182}=\right.$ 4.732; $P<0.001)$. According to the Tukey post hoc analysis results $(\alpha=0.05)$, this difference was influenced by the visiting pattern of C.(C.) aenea, C. (H.) analis, C. (C.) nitens, and C. (H.) tarsata (Figure 3, Table I). Otherwise, neither the total number of visits $\left(F_{1,182}=1.995, P=0.164\right)$ between years nor the total number of visits made by each species $\left(F_{8,8}=1.975,0.20<P<0.50\right)$ differed significantly.

We also found that the visiting frequencies of the nine most frequent species differed among themselves in the first year $\left(F_{8,90}=5.957, P<0.001\right)$ and in the second year $\left(F_{8,90}=7.631, P<0.001\right)$.

Table II. Species richness estimation of Centridini bees by different estimators.

\begin{tabular}{lccrr}
\hline & ICE mean & Chao 2 & Jack 1 & Jack 2 \\
\hline Year 1 & $22.29 \pm 0$ & $21.1 \pm 1.71$ & $23.67 \pm 2.82$ & $23.97 \pm 0$ \\
Year 2 & $23.72 \pm 0$ & $21.44 \pm 3.9$ & $23.5 \pm 2.14$ & $26.23 \pm 0$ \\
Total & $24.79 \pm 0$ & $23.48 \pm 0.99$ & $25.88 \pm 1.59$ & $24.24 \pm 0$ \\
\hline
\end{tabular}



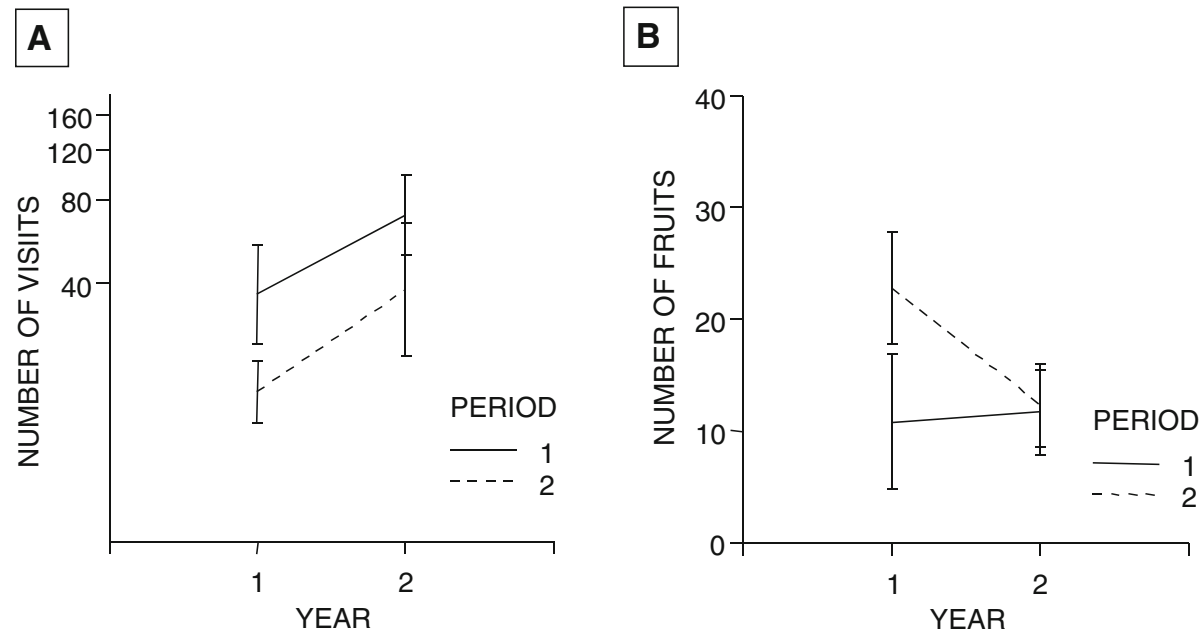

Figure 2. Number of visits of Centridini bees $( \pm \mathrm{SD})$ to Malpighia emarginata flowers (a) and number of fruits formed $( \pm \mathrm{SD})(\mathbf{b})$ during 2 years in a study carried out at the Água Limpa Experimental Station, Uberlândia. Year 1 (2006-2007) and Year 2 (2007-2008) (period 1-October-November; period 2-January-February).

Likewise, there was a fluctuation in fruit production (Figure 4). In some samples from $\mathrm{Y}_{1}$, we observed a larger percentage of natural fruit set than the potential established for $M$. emarginata. However, the number of fruits produced was not different between the periods $\left(F_{1,1}=3.742, P>0.500\right)$ or years $\left(F_{1,18}=1.152\right.$,

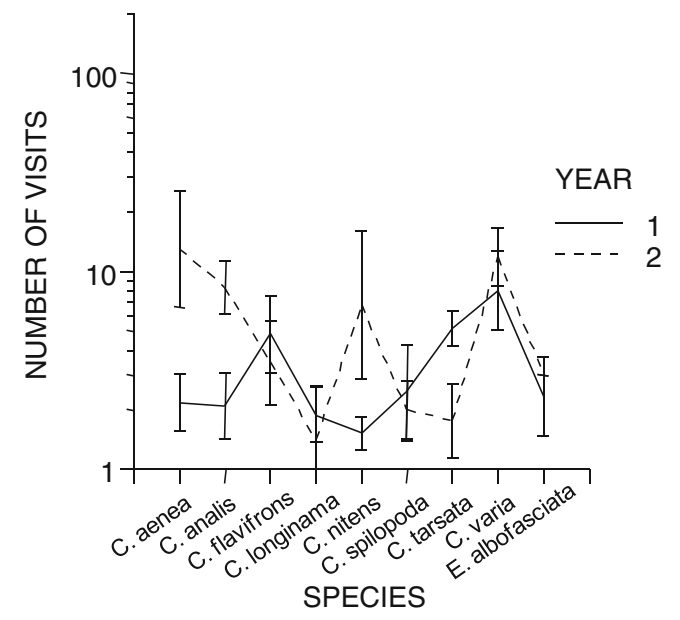

Figure 3. Fluctuations in the frequency of visits $( \pm \mathrm{SD})$ of the most frequent Acerola (Malpighia emarginata) visitors at the Água Limpa Experimental Station, Uberlândia, MG. Year 1 (2006-2007) and Year 2 (2007-2008).
$P=0.297$ ) (Figure 2b). Furthermore, there was no interaction between the two factors $\left(F_{1,18}=\right.$ $0.590, P=0.453$ ).

The fluctuation in fruit set was not correlated with the number of visits in either the first year $\left(r_{0.05 ;(2) ; 10}=0.086 ; P=0.802\right)$ or the second year $\left(r_{0.05 ;(2) ; 10}=-0.083 ; P=0.809\right)$.

\subsection{Mutualistic network}

The pollination network was, according to the criteria for selecting bee species, composed of seven Acerola visitors, namely Epicharis (Epicharana) flava, C. (C.) flavifrons, C. (C.) aenea, C. (C.) varia, Centris (Ptilotopus) scopipes, C. (C.) spilopoda, and C. (T.) longimana, with 16 plant species and four pollen types belonging to seven families (Figure 5).

The network exhibited a nested pattern with an NODF value of 55.61. This measurement was statistically significant according to the first null model $\left(p_{\mathrm{ER}}=0.01\right)$ but not significant according to the second null model $\left(p_{\mathrm{CE}}=0.12\right)$. Furthermore, among the 140 interactions that were theoretically possible, only $58(C=41 \%)$ were observed.

The average degree of bee species $( \pm$ SD) was $0.143 \pm 0.041$, while the average degree of plant species was $0.050 \pm 0.041$. Regarding food resour- 


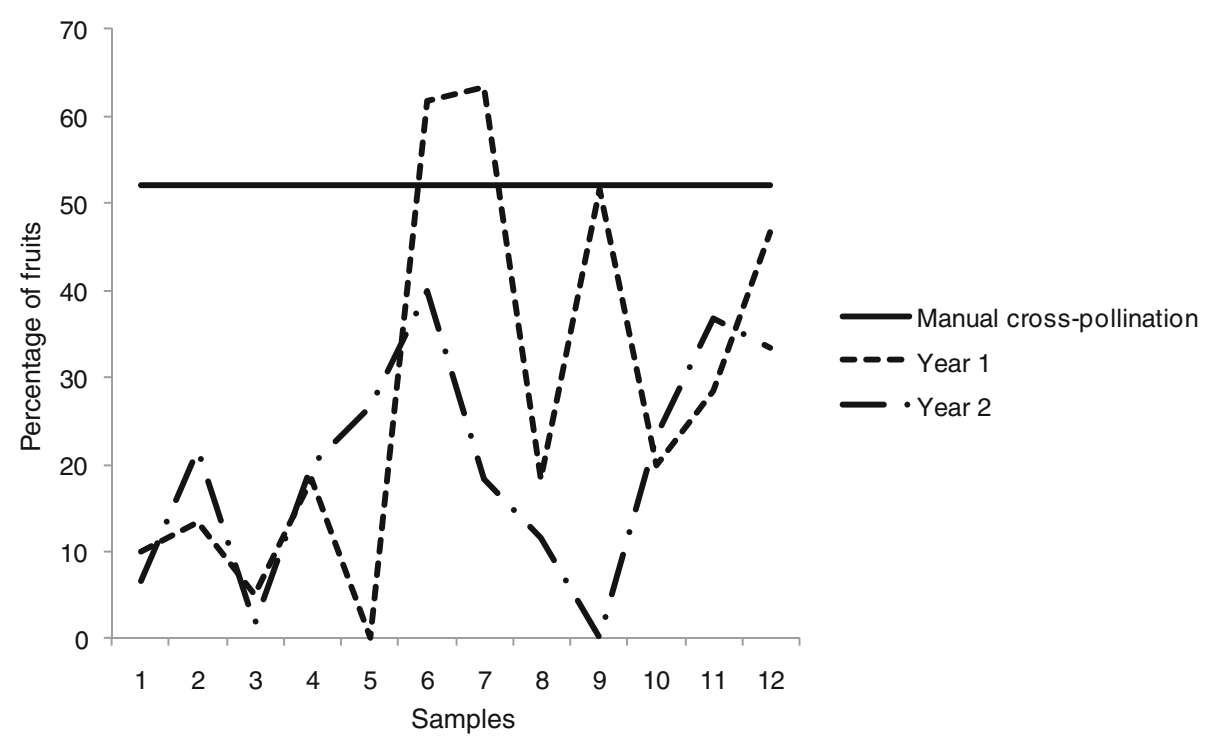

Figure 4. Percentage of fruits formed by natural pollination during the different sampling periods in years 1 (2006-2007) ( $n=60$ for each sample) and 2 (2007-2008) ( $n=60$ for each sample) in an area of Malpighia emarginata orchard at the Água Limpa Experimental Station, Uberlândia, MG. The numbers 1 to 6 represent period 1 and the numbers 7 to 12 represent period 2. The solid line represents the percentage of fruits formed by manual cross-pollination $(n=50)$.

ces, no bee species relied on a single plant species, and two species $(28.6 \%)[C$. (C.) flavifrons and $E$. (E.) flava] used a greater number of plant species than average. Eight plant species $(40 \%)$ were used as food resources by only one of the bee species and seven species $(35 \%)$ were used with above-average frequency (M. emarginata, Byrsonima type, Heteropterys type, Solanum lycocarpum, Caesalpinea peltophoroides, Acosmium dasycarpum, and Distictella elongata).

Malpighia emarginata, Byrsonima type, Heteropterys type, and $S$. lycocarpum were important food resources for all of the studied bee species. Malpighia emarginata accounted for $72.30 \%$ of all the pollen grains present in the C. (C.) varia samples and $35.09 \%$ of the $C$. (C.) aenea samples. The Byrsonima type was the most important resource for $E$. (E.) flava (42.34\%) and C. (C.) spilopoda (43.82\%). The Heteropterys type accounted for $53.46 \%$ of the food resources for $C$. (P.) scopipes and $25.80 \%$ of the resources for C. (C.) flavifrons. Solanum lycocarpum accounted for $34.20 \%$ of the resources for $C$. (T.) longimana.

\section{DISCUSSION}

The richness of Centridini bees found visiting the Acerola crop was considered very high compared to the values obtained in other studies (Freitas et al. 1999; Oliveira and Schlindwein 2003). The species accumulation curve showed a tendency towards stabilization only when both years were jointly analyzed, demonstrating the importance of long-term studies for estimating richness and for monitoring the populations of pollinators.

The high richness observed could have been associated with the presence of Cerrado remnants around the crop. The occurrence of natural areas is considered important for bee conservation (De Marco and Coelho 2004; Ricketts 2004; Ricketts et al. 2004, 2008; Kremen 2008) because they provide nesting sites and plant resources for nest building and feeding. Furthermore, several studies have confirmed that the Malpighiceae is one of the most representative families of the Cerrado (Weiser and Godoy 2001) and that there are positive and reciprocal population effects 


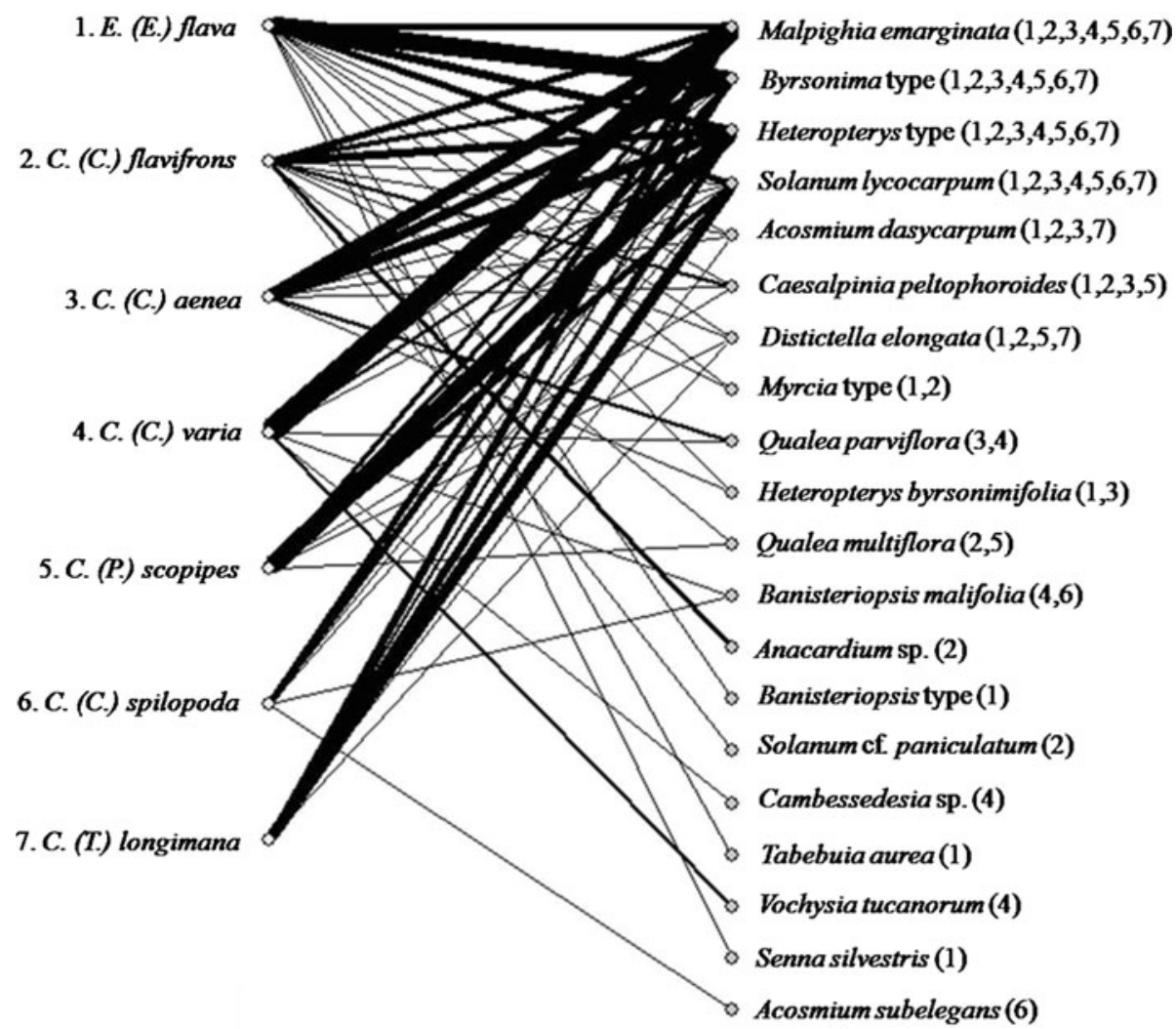

Figure 5. Mutualistic network of seven bee species that pollinated Malpighia emarginata at the Água Limpa Experimental Station, MG, from 2004 to 2008. The lines represent the interactions (the thicker the line, the stronger the interaction), the circles on the left represent the bees and the circles on the right represent the plants.

between this family and Centridini bees (Ramalho and Silva 2002).

Variations in natural fruit set, as observed in this study, are expected for hermaphrodite plants that produce many flowers when considering that the high energy cost of fruit and seed production can lead to abortions and thus lower fruit sets in some periods (see Guittian 1993). This variation could also be associated with fluctuations in the number of visiting bees between periods and years, but this correlation was not observed. In conclusion, the temporal variation in abundance of Centridini bees did not affect Acerola production.

The fluctuation in the number of visits shown by the most frequent species seemed to result in a substitution over time, i.e., when a species was rarely observed on the cultivar there was another that visited its flowers more often. Such a turnover is possible because of the high richness of Centridini bees that were observed to frequent the Acerola orchard and which may have a compensatory effect on the shrubs by reducing the impact of a lack of pollinators (Kremen 2004).

The Centridini bees analyzed in this study visited a variety of flora for their resources, which included nectar, pollen, and oil. However, analysis of the pollination network demonstrated a strong association between seven Centridini species and only four plant species, with $M$. emarginata serving as an oil source for the majority of Acerola visitors (Vilhena and Augusto 2007). This asymmetry was reflected 
in the network structure since it was only considered as nested for the less conservative null model.

On the other hand, the absence of nestedness, considering the number of interactions performed by the species (the more conservative null model), may have been due to the analysis being limited to a restricted set of bees, most of which showed a similar number of interactions (the degree).

Centris (C.) flavifrons and E. (E.) flava showed an above-average number of interactions. According to Bezerra et al. (2009), the most common species or those that present a higher degree of generality in interactions (see Bascompte et al. 2003) are mainly responsible for maintaining ecological services.

The connectance observed in this study was higher than that found in other interaction networks (see Biesmeijer et al. 2005; Pigozzo and Viana 2010). This result may be attributable to the close relationship between Centridini bees and oil plants, such as Malpighiaceae, increasing the possibility of interactions in the mutualistic networks.

A high level of interactions between certain components of a network can provide greater stability to the system since this allows the replacement of some species over time (Bascompte et al. 2003). Another fact that may influence the nested structure verified by null model I is the network composition. Networks that consider species with close relationships are a subweb of the whole network and are considered as being more resilient and nested (Bezerra et al. 2009).

The results suggest that the high species richness of Centridini bees and the stability of the pollination network may have a compensatory effect on Acerola crops, which, despite temporal variations in the frequency of individual visits, ensures good rates of natural pollination.

Many efforts have been made to propagate and manage various bee species for crop pollination in Brazil, including Centridini species. This study is an attempt to improve such efforts by providing basic information about the conservation and management of Acerola pollinators, in addition to demonstrating the viability of cultivating this fruit in the Brazilian Cerrado. Besides, our findings indicate that the Acerola fruit set is benefited by the pollinators diversity ensured by the presence of natural lands surrounding the crop, as proposed by other studies (De Marco and Coelho 2004; Ricketts 2004; Ricketts et al. 2004, 2008; Morandin and Winston 2006; Kremen 2008). In conclusion, long-term studies about diversity of pollinators in crops and the complex network interaction among them and the natural vegetation will allow a more precise management of the agricultural landscape for enhance pollination services.

\section{ACKNOWLEDGMENTS}

This research was financially supported by the Fundação de Amparo à Pesquisa de Minas Gerais (FAPEMIG). We are grateful to Paulo Eugênio Oliveira for suggestions, to Heraldo Luis de Vasconcelos for help in the statistical analyses, to employees of the Água Limpa Experimental Station for technical help and to anonymous reviewers that contributed to improve the manuscript. Alice M. G. F. Vilhena received a grant from FAPEMIG.

Pollinisateurs de l'acérola dans la savanne du Centre du Brésil: variations dans le temps de la richesse en abeilles récolteuses d'huile et réseau d'interactions insectes-végétaux

Centridini / pollinisation / réseau interactif / abeilles / arbre fruitier / Malpighia emarginata

Bestäuber der Westindischen Kirsche (Acerola) in der Savannenregion Zentralbrasiliens: Zeitliche Variation in der Präsenz von Ölbienen und ein mutualistisches Netzwerk

\section{Centridini / Landwirtschaft / Bestäubung / Interaktionsnetzwerk / Biene}

\section{REFERENCES}

Almeida-Neto, M., Guimarães, P.R., Guimarães, J.R.P.R., Loyola, R.D., Ulrich, W. (2008) A consistent metric for nestedness analysis in ecological systems: reconciling concept and measurement. Oikos 117, 1227-1239 
Bascompte, J., Jordano, P., Melián, C.J., Olesen, J.M. (2003) The nested assembly of plant-animal mutualistic networks. Proc Natl Acad Sci USA 100, 9383-9387

Bascompte, J. (2007) Networks in ecology. Basic Appl. Ecol. 8, 485-490

Batagelj, V., Mrvar, A. (1998) Pajek — program for large network analysis. Connections 21, 47-57

Bezerra, E.L.S., Machado, I.C., Mello, M.A.R. (2009) Pollination networks of oil-flowers: a tiny world within the smallest of all worlds. J. Anim. Ecol. 78, 1096-1101

Biesmeijer, J.C., Slaa, E.J., Castro, M.S., Viana, B., Kleinert, A.M.P., Imperatriz-Fonseca, V.L. (2005) Connectance of Brazilian social bee-food plant networks is influenced by habitat, but not by latitude, altitude or network size. Biota Neotrop. 5 (1), 85-93

Carvalho, A.M.C., Bego, L.R. (1996) Studies on Apoidea fauna of cerrado vegetation at the Panga Ecological Reserve, Uberlândia, MG, Brazil. Rev. Bras. Entomol. 40, 147-156

Colwell, R.K. (2006) EstimateS: statistical estimation of species richness and shared species from samples. Version 8.0. User's guide and application [online] http://viceroy.eeb.uconn.edu/estimates (accessed on 28 April 2011)

De Marco Jr., P., Coelho, F.M. (2004) Services performed by the ecosystem: forest remnants influence agricultural cultures' pollination and production. Biod. Conserv. 13, 1245-1255

Erdtman, G. (1960) Angiosperms (An Introduction to Palynology. I). Pollen Morphology and Plant Taxonomy. Chronica Botanica, Waltham

Freitas, B.M., Alves, J.E., Brandão, G.F., Araújo, Z.B. (1999) Pollination requirements of Acerola (Malpighia emarginata) and its putative pollinators, Centris bees, in NE Brazil. J. Agric. Sci. Cambridge 133, 303-311

Guimarães, P.R., Guimarães, P. (2006) Improving the analyses of nestedness for large sets of matrices. Environ. Modell. Softw. 21, 1512-1513

Guimarães, P.R., Sazimal, C., Reis, S.F., Sazima, I. (2007) The nested structure of marine cleaning symbiosis: is it like flowers and bees? Biol. Lett. 22, 3(1), 51-54

Guittian, J. (1993) Why Prunus mahaleb (Rosaceae) produces more flowers than fruits. Am. J. Bot. 80 (11), 1305-1309

IBGE - Instituto Brasileiro de Geografia e Estatística (2006) Produção nos estabelecimentos agropecuários com mais de 50 pés existentes - Brasil 2006 [online] htts:/www.ibge.gov.br/home/estatistica/economia/ agropecuaria/censoagro/ (accessed on 28 April 2011)

Kearns, C.A., Inouye, D.W. (1993) Techniques for Pollination Biologists. University Press of Colorado, Niwot

Klein, A.M., Vaissiere, B.E., Cane, J.H., Steffan-Dewenter, I., Cunningham, S.A., Kremen, C. (2007) Importance of pollinators in changing landscapes for world crops. Proc. R. Soc. B Biol. Sci. 274, 303-313

Kremen, C. (2004) Pollination services and community composition: does it depend on diversity, abundance, biomass or species traits? In: Freitas, B.M., Pereira, J.O.P. (eds.) Solitary Bees: Conservation, Rearing and Management for Pollination, pp. 115-124. Imprensa Universitária, Fortaleza

Kremen, C. (2008) Crop pollination services from wild bees. In: James, R.R., Pitts-Singer, T.L. (eds). Bee Pollination in Agricultural Ecosystems, pp. 10-26. Oxford University Press, Oxford

Maia, M., Russo-Almeida, P.A., Pereira, J.O. (2005) Caracterização do espectro polínico dos méis de Alentejo (Portugal). Silva Lus. 13, 95-103

Miyashita, R.K., Nakasone, H.Y., Lamoureux, C.H. (1964) Reproductive morphology of Acerola (Malpighia glabra L.), Hawaii Agr. Exp. Stat., Technical Bulletin. Honolulu, Hawaii. n. 63

Morandin, L.A., Winston, M.L. (2006) Pollinators provide economic incentive to preserve natural land in agroecosystems. Agric. Ecosyst. Environ. 116, 289-292

Neto, P.L. (2008) Levantamento planimétrico $n^{\circ} 36.243$, Prefeitura de Uberlândia, Minas Gerais

Oliveira, M.D., Schlindwein, C. (2003) Espécies de Centris e Epicharis (Apidae, Centridini) como polinizadores de Malpighia emarginata (acerolaMalpighiaceae) na Zona da Mata em Pernambuco, pp. 224-225. Anais de trabalhos completos do VI Congresso de Ecologia do Brasil. Fortaleza, CE

Oliveira, R., Schlindwein, C. (2009) Searching for manageable pollinator for Acerola orchards: the solitary oil-collecting bee Centris analis (Hymenoptera: Apidae: Centridini). Hortic. Entomol. 102, 265-273

Pigozzo, C.M., Viana, B.F. (2010) Estrutura da rede de interações entre flores e abelhas em ambiente de caatinga. Oecol. Aust. 14(1), 100-114

Ramalho, M., Silva, M. (2002) Flora oleífera e sua guilda de abelhas em uma comunidade de restinga tropical. Sitientibus Série Ciências Biológicas 2(1/2), 34-43

Richards, A.J. (1986) Plant Breeding Systems. Unwin \& Allen, London

Roubik, D.W., Moreno, J.E. (1991) The pollen and spores of Barro Colorado Island. Monographs in Systematic Botany from the Missouri Botanical Garden, St Louis, MO, USA

Roubik, D.W. (1995) Pollination of Cultivated Plants in the Tropics. Food and Agriculture Organization, Rome

Ricketts, H.T. (2004) Tropical forest fragments enhance pollinators activity in nearby coffee crops. Conserv. Biol. 18, 1262-1271

Ricketts, H.T., Daily, G.C., Ehrlich, P.R., Michener, C. D. (2004) Economic value of tropical forest to 
coffee production. Proc. Natl. Acad. Sci. USA 101, 12579-12582

Ricketts, T.H., Regetz, J., Steffan-Dewenter, I., Cunningham, S.A., Kremen, C., Bogdanski, A., Gemmill-Herren, B., Greenleaf, S.S., Klein, A.M., Mayfield, M.M., Morandin, L.A., Ochieng, A., Viana, B.F. (2008) Landscape effects on crop pollination services: are there general patterns? Ecol. Lett. 11, 499-515

Salgado-Labouriau, M.L. (1973) Contribuição à Palinologia dos Cerrados. Academia Brasileira de Ciências, Rio de Janeiro

Silveira, F.A., Campos, M.J.O. (1995) A melissofauna de Corumbataí (SP) e Paraopeba (MG) e uma análise da biogeografia das abelhas do cerrado brasileiro (Hymenoptera, Apoidea). Rev. Bras. Entomol. 39, 371-401

Souza, M.J.H., Guimarães, M.C.A., Guimarães, C.D.L., Freitas, W.S., Oliveira, A.M.S. (2006) Potencial agro- climático para a cultura da acerola no Estado de Minas Gerais. Rev. Bras. Eng. Agríc. Ambient. 10, 390-396

Vilhena, A.M.G.F., Augusto, S.C. (2007) Polinizadores da aceroleira Malpighia emarginata DC (Malpighiaceae) em área de cerrado no Triângulo Mineiro. Biosci. J. 23, 14-23

Weiser, V.L., Godoy, A.A.P. (2001) Florística em um hectare de Cerrado stricto sensu na ARIE-Cerrado Pé-de-Gigante, Santa Rita do Passo Quatro, SP. Acta Bot. Bras. 15, 201-212

Williams, I.H., Corbet, S.A., Osborne, J. (1991) Beekeeping, wild bees and pollination in the European Community. Bee World. 72, 170-180

Yamane, G.M., Nakasone, H.H. (1961) Pollination and fruit set studies of acerola Malpighia glabra L. in Hawaii. Proc. Am. Soc. Hortic. Sci. 78, 141148

Zar, J.H. (1999) Biostatistical Analysis, 4th edn, p. 660. Prentice Hall, Upper Saddle River 